\title{
ULOGA MEDIJSKE KONVERGENCIJE U RAZVOJU KULTURNIH I KREATIVNIH INDUSTRIJA
}

\author{
Danica Čigoja Piper*, \\ Tijana Radojević, \\ Milica Čolović, \\ Nikica Radović
}

Univerzitet Singidunum, Beograd, Srbija

Odgovorno lice:

Danica Čigoja Piper

e-pošta:

danica.cigoja@fmk.edu.rs

\section{Rezime:}

Imajući u vidu medijsku konvergenciju kao jedno od obeležja medija i medijski posredovanog poslovanja u digitalnom svetu, glavni cilj ovog rada je razumevanje medijske konvergencije kao izazova savremenog društva i to kroz prizmu globalne ekspanzije kulturnih i kreativnih industrija. Cilj ovog rada je i da ponudi analizu povezanosti procesa medijske konvergencije i razvoja kulturnih i kreativnih industrija. Glavna teza predstavljena u radu je da proces medijske konvergencije pozitivno utiče na razvoj kulturnih i kreativnih industrija, te da su medijska konvergencija - u najvećoj meri podstaknuta informacionim tehologijama i digitalizacijom sveta oko nas - i različiti kreativni procesi u društvu usko povezani.

Ključne reči:

mediji, telekomunikacije, digitalizacija, kultura, kreativnost.

\section{UVOD}

Munjeviti razvoj digitalnih tehnologija u 21. veku doveo je do stvaranja novih medijskih formi koje se, upravo zbog brzine tehnoloških promena i tržišnih prilika, suočavaju sa neprekidnom transformacijom. Najveća promena u pojavnim oblicima medija ogleda se u kreiranju svojvrsne mreže medijskih usluga zasnovane na sinergiji mobilne tehnologije, tradicionalnih elektronskih medija, informacionih tehnologija i interneta. Tako ukršteno delovanje medija, IT sektora i telekomunikacija dovelo je do razvoja pojma medijska konvergencija koji podrazumeva novi oblik komuniciranja u postojećem digitalnom prostoru. Ovakav vid razmene sadržaja smatra se težnjom ka univerzalizaciji medija, odnosno ka kreiranju iskustva upotrebe jedinstvenih medijskih i različitih komunikacionih usluga posredstvom različitih uređaja, a sve zahvaljujući snažnoj mrežnoj povezanosti i visoko razvijenoj tehnološkoj podršci.

Prema Henriju Dženkinsu (Henry Jenkins), koji je fokus svog teorijskog rada i istraživanja postavio u sferi ispitivanja kulturne konvergencije, medijska konvergencija nije samo proizvod novih dostignuća u domenu digitalnog, već predstavlja proizvod „povezanosti postojećih tehnologija, industrija, tržišta, žanrova i publika” [1]. Medijska konvergencija, prema ovom autoru, nije krajnji rezultat delovanja više ukrštenih 
faktora sa zajedničkim ciljem - pravovremeno, jasno i tačno informisanje - već je to proces promene medijske logike koji traje i koji će, kao uvek iznova tehnološki uslovljen, trajati. „Zahvaljujući ubrzanom rastu kanala (komunikacije) i mogućnosti brzog prenošenja novih kompjuterskih i telekomunikacionih uređaja, ulazimo u eru gde će mediji biti svuda i koristićemo različite vrste medija povezane jedne sa drugima" [1]. Ovo više decenija građeno teorijsko predviđanje Dženkinsa, danas je i empirijski potvrđeno. Savremeno društvo u velikoj meri se oslanja na niz medija bez kojih ljudi ne mogu zamisliti svoju svakodnevicu. Najčešće su brojni medijski sadržaji dostupni u mobilnom telefonu korisnika, a kada korisnik, uz mobilni telefon, poseduje i računar ili tablet, onda su, kao po komandi, svi posedujući uređaji povezani posredstvom odgovarajućeg softvera - recimo nalozi podržavajući od strane Gugla (Google) ili Epla (Apple). Ukoliko korisnik ima mogućnost da živi u domu koji je organizovan po principu pametne kuće onda je sigurno da je i taj aspekt života umrežen sa mobilnim telefonom, posredstvom odgovarajuće aplikacije. Reč je o medijskoj konvergenciji na delu. Takav vid tehnološkog upliva u svakodnevni život sve je prisutniji i zbog toga je neophodno da stalno preispitujemo proces medijske konvergencije i da ga usavršavamo, posebno u onim poljima gde je moguće da dođe do izostanka neophodnog nivoa kontrole ovog procesa od strane njegovih kreatora u različitim industrijama (programeri i drugi stručnjaci u IT sektoru i u telekomunikacijama, urednici medija, dizajneri, novinari, zaposleni u različitim kreativnim i komunikacionim delatnostima...).

U složenom procesu konvergencije medija posebnu ulogu igraju telekomunikacione kompanije koje poseduju visok nivo finansijske podrške za razvoj digitalizacije medijske komunikacije, imaju razvijen sistem održavanja mreže krajnjih korisnika i sposobnost brzog prilagođavanja novim tehnologijama. Kao takve, one „poseduju potencijal da preuzmu centralnu ulogu u oblikovanju i popularizaciji novih informacijskih usluga" [2]. Prema Crnobrnji, na taj potencijal moraju računati svi koji se bave medijima i imati na umu da "telefonske organizacije ne nameravaju da prihvate samo ulogu izvođača i konstruktora u razvoju globalne informacijske infrastrukture"[2], već da je njihov cilj da preuzmu i kontrolu nad sadržajem medijskih proizvoda, kao i da postanu vodeće organizacije na medijskom tržištu. Otud i sve češći upliv telekomunikacionih kompanija u poslovanja medijskih kuća (kupovinom postojećih medija i kreiranjem sopstvenih medijskih platformi).

\section{MEDIJSKA KONVERGENCIJAU KULTURNIM I KREATIVNIM INDUSTRIJAMA}

Kulturne i kreativne industrije predstavljaju spoj različitih delatnosti koje se zasnivaju na razvoju kreativnih potencijala. Kreativne industrije obuhvataju različite vrste dizajna, izdavaštvo, telekomunikacije, medije, modu, film, video i fotografiju, softvere, kompjuterske igre, igračke, muziku, vizuelne i izvođačke umetnosti, zanate, advertajzing i drugo [3]. Kreativne i kulturne industrije postale su neumitni pokretači razvoja mnogih privreda širom sveta i, kao takve, doprinose ubrzanim promenama na različitim tržištima. „Ekonomski doprinos kreativnih industrija ogleda se u nizu ekonomskih i neekonomskih efekata, kao što su: prihodi od izvoza, nova radna mesta, unapređenje informaciono-komunikacionih tehnologija, jačanje kolektivizma, kreiranje mišljenja pojedinca, brendiranje područja i sl." [4]. Međutim, vrednost kulturnih i kreativnih industrija nije ograničena samo na izraženi doprinos ekonomiji. „Njihova važnost ne proizilazi samo iz utvrđene činjenice da pokreću ekonomiju znanja i omogućuju rad drugih delatnosti. One uspostavljaju nove obrasce društvenog razvoja i društvene strukture"[5].

U novijoj literaturi srećemo i autore koji smatraju da kreativne industrije obuhvataju šire polje od kulturnih industrija [6], ali u ovom radu kulturna i kreativna industrija posmatraju se kao neodvojive celine jednog pravca u savremenoj ekonomiji - prostor upotrebe ljudske kreativnosti radi sticanja profita u konkretnom poslovnom projektu.

Kako se medijska konvergencija može dovesti u vezu sa kulturnim i kreativnim industrijama, ovim sve ekspanzivnijim sektorima, u savremenom svetu? Ta veza je veoma logična - kao i kod drugih sektora kojima su medijski proizvodi platforma za stvaranje proizvoda, a medijska vidljivost garancija za opstanak - mediji su vodeći kanal za prenošenje informacija od pošiljalaca do primalaca, te je bilo koja ideja koju je neophodno sprovesti u delo ili promovisati, okrenuta ka upotrebi medija. Neki autori smatraju da su promene koje dovode do procesa konvergencije medija i kreativnost (kao talenat koji je nužni potencijal za razvoj kreativnih i kulturnih sektora, a time i čitavih industrija u tom polju) neraskidivo povezani i da nije moguće jasno sagledati koja je od dve strane inicijator postojanja druge. Prema Dženkinsu, „upravo sada, kulturne promene, pravne bitke i ekonomska konsolidacija koje podstiču medijsku konvergenciju prethode pomacima u tehnološkoj infrastrukturi” [1]. Rezultat ove uzročno posledične veze 
ukazaće na to gde će se zadržati koncentracija kapitala i moći. „I u teoriji i u praksi postoji opšta saglasnost oko sledeće teze: ko bude raspolagao infrastrukturama spremnim za elektronski prenos i brzi pristup informacijama, imaće presudnu prednost u budućem ekonomskom, socijalnom i kulturnom razvoju" [2].

Prema Kisić, kulturne i kreativne industrije podrazumevaju sposobnost brze reakcije na sve češće promene u tehnološkim aspektima poslovanja. „Digitalna eksploatacija prava autora nudi mnoge nove mogućnosti i prilike na polju kreativnih industrija. Softveri, razvoj novih aplikacija, upravljanje podacima i elektronsko umrežavanje od velike su važnosti za sektor. To je razlog zašto je informatička i tehnološka pismenost među profesionalcima i širom populacijom jedan od preduslova za stalni razvoj sektora i konkurentnosti na globalnom tržištu" [6].

Mogućnosti koje medijska konvergencija nudi korisnicima medija sa jedne (pošiljaoci medijskih poruka) i sa druge strane (primaoci medijskih poruka) sve su brojnije i sve neophodnije za svaku delatnost, a ponajviše za delatnosti koje se oslanjaju na kreativnost. U tom smislu, upotreba medijskih kanala dostupnih zahvaljujući sve razvijenijem IT sektoru na globalnom medijskom tržištu (podjednako i hardverskom i softverskom) postaje vodeća potreba kreativnih sektora u različitim industrijama, čime se neprestano obnavlja potreba za posmatranjem kreativne industrije kao grane per se u savremenoj - novoj - ekonomiji.

U svetu koji svakodnevno postaje iznova posredovan medijima, konvergencija u domenu ekonomije podrazumeva proces koji je ponekad vođen od strane korporacija, a ponekad je određen isključivo aktivnošću potrošača. Dženkins objašnjava zbog čega medijska konvergencija biva inicirana, odnosno oblikovana, iz dva izvora: „medijske kompanije uče kako da ubrzaju protok medijskih sadržaja kroz kanale isporuke kako bi obezbedili veće mogućnosti prihoda, proširili tržišta i pojačali obaveze gledalaca. Potrošači uče kako da koriste ove različite medijske tehnologije kako bi potpunije kontrolisali protok medija i kako bi ostvarili interakciju sa drugim korisnicima" [1]. Tako postavljena logika poslovanja u kreativnom sektoru stvara mogućnosti za pozicioniranje različitih proizvoda ili usluga u dominantno vizuelnim medijima. Na primer, $\mathrm{u}$ filmskoj industriji, danas se podrazumeva da će nekoliko proizvoda iz asortimana sponzora konkretnog projekta biti deo niza kadrova u filmskom ostvarenju i to kroz koncept pozicioniranja proizvoda, odnosno brenda (product - brand placement) koji podrazumeva postavljanje specifičnih (odabranih) proizvoda u određeni kadar i upotreba naziva brendova u filmskim i televizijskim scenarijima. [7]. Takav vid upotrebe medijskog sadržaja - radi promocije brenda - nije novina, prisutan je u javnosti još od pojave prvih audio-vizuelnih medija, ali u 21. veku postaje sve prisutniji i dovodi do toga da se pojedini filmovi snimaju isključivo radi promocije proizvoda onih koji finansiraju produkciju tog filma (reč je najčešće o filmovima koji pripadaju žanru komedije i čiji je glavni cilj puka zabava gledalaca - uz, naravno, meko ubeđivanje gledalaca da postanu kupci proizvoda koji se u filmu pojavljuju). I sve popularnija rijaliti (reality) forma televizijske zabave podrazumeva obavezu reklamiranja određenih proizvoda pod plaštom upotrebe istih u toku programa, a od strane učesnika datog programa. Tako će akteri određenog rijaliti formata tokom čitave sezone konzumirati isključivo jednu vrstu, odnosno odabrani brend, gaziranog ili alkoholnog pića, nosiće garderobu ili modne detalje u boji karakterističnoj za sponzore tog programa i slično. Ovi primeri već uveliko su empirijski potvrđeni u gotovo svakom rijaliti programu na lokalnim televizijskim stanicama, ali i globalno, u mnogim stranim medijima.

Važan aspekt izražavanja zaposlenih u kulturnim i kreativnim industrijama je naracija posredstvom medija, odnosno umeće kreiranja priče koja interesnoj grupi može učiniti dopadljivom ili prodati određenu ideju, neki proizvod ili uslugu. Ovaj koncept u savremenim studijama medija označen je terminom storiteling (storytelling), ili tehnika storitelinga, a u osnovi predstavlja veštinu pričanja priča radi ispunjenja određenog cilja. Prema Salmonu, storiteling je neodvojivi deo života savremenih ljudi i upravo narativi oko nas utiču na to šta ćemo birati u moru nametnutih izbora [8]. Oslanjajući se na pričanje priča, kreativci danas mogu prilagoditi jedinstvenu ideju izrazu različitih medijskih platformi i medijskih žanrova, čime se omogućava "opkoljavanje" ciljnih grupa datom idejom i navođenje na akciju (recimo, kupovinu ili očekvano delovanje).

Medijska konvergencija omogućila je savremenom svetu da pojedinac samostalno organizuje upotrebu medijskog sadržaja. Ova pojava veoma je interesantna za istraživače u oblasti medija, jer podrazumeva da više nije neophodno da postoji profesionalna selekcija sadržaja u medijima. Pored novinara i urednika, transformaciju medija vrše i korisnici medija. Dovoljno je da je korisnik medijski i tehnološki opismenjen i on će, kao takav, samostalno vršiti selekciju dostupnog sadržaja i kreirati lični program za informisanje, zabavu i edukaciju. Pored toga, pojavom interneta, javnost odavno nije prostor informisanja isključivo posredstvom medija koji imaju 
jasnu uredničku i novinarsku strukturu i koji su kao takvi registrovani, već prosečan korisnik interneta brojne (dez)informacije saznaje na različitim društvenim mrežama ili na portalima sa sadržajem sumnjivog porekla i nepostojećeg impresuma. Takva promena predstavlja izazov upravo za radnike u kreativnim sektorima - u tradicionalnim medijima, ali i u drugim sferama koje zahtevaju povezanost sa medijima (film, dizajn, umetnost, pozorište i druge kulturne institucije...). Prema Snježani Milivojević „urušio se poslovni model na kojem postoji medijska industrija kakvu poznajemo" [9]. Dakle, medijski radnici više nisu jedini tvorci sadržaja, a njihova uloga nije ograničena na pripremu i objavljivanje vesti, već je proširena obavezom filtriranja i provere autentičnosti vesti koje sa svih strana dolaze kao rezultati javne razmene u digitalnoj sferi, preciznije na internetu (na već pomenutim društvenim mrežama, na forumima i sl.)

Kulturne i kreativne industrije u velikoj meri koriste mogućnosti koje novi mediji omogućavaju u procesu konvergencije i to kroz njihove tri vodeće odlike. Reč je o multimedijalnosti, interaktivnosti i povezanosti tekstova u vidu hipertekstualnosti. Ova tri principa pomažu da se razume priroda novih medija koji su osnova medijske konvergencije, ali i da se shvati potencijal koji savremeni mediji imaju u polju kulturnih i kreativnih industrija. Prema Kljajiću, pojam multimedijalnost odnosi se direktno na medijsku konvergenciju i spajanje tradicionalnih i novih medija u novi medijski pojavni oblik koji čine tekstovi, grafike, tabele, audio i video programi. [10]. Interaktivnost podrazumeva aktivno učešće javnosti u komentarisanju medijskih sadržaja, čime se omogućava dvosmernost u komunikaciji[10]. Iako dvosmerna, ova komunikacija uvek je kontrolisana od strane medijske kuće koja omogućava datu razmenu informacija i koja obavezno vrši moderaciju poslatih komentara. Za medijsku konvergenciju takođe je važan hipertekst koji podrazumeva povezivanje tekstova u vidu mreže. Različiti tekstovi na internetu su na određeni način umreženi i usmereni jedni ka drugima, posredstvom linkova, a kao takvi, prema Levu Manoviču (Lev Manovich), liče na svojevrsne korene rizoma - razbacane i naizgled nepovezane [11]. Iako rizomski postavljeni, linkovani tekstovi, zapravo, omogućavaju lakšu navigaciju kroz tekstove na istoj ili na različitim platformama, a ujedno utiču na korisnika da ide putanjom koju mu kreator sadržaja namenjuje. Tri navedena principa medijske konvergencije ukazuju na mogućnosti koje mediji današnjice pružaju u kulturnim i kreativnim industrijama. Povezivanje nebrojene količine informacija u formama koje uključuju tekst, fotografije, video, različite grafike, zvuk, pomažu distribuciju poruka do što veće grupe primalaca istih. Kod milenijalaca (millennials), odnosno mladih koji su rođeni krajem 20. i početkom 21. veka, medijsko postojanje - posredovano mobilnim telefonima, tabletima i drugim, najčešće lako prenosivim uređajima najnovije generacije - često je jedino uvaženo postojanje ono digitalno. Njihova vodeća navika je informisanje putem savremenih tehnologija, kompeticija u digitalnim izazovima (video igrice, zabavni i ponekad opasni izazovi na društvenim mrežama) kao i lična afirmacija posredstvom (u datindikatori kulturnih i kom trenutku) popularnih medijskih kanala, pa se može pretpostaviti da će medijska konvergencija imati veliki uticaj na njihov svakodnevni rad (ako pretpostavimo se da će deo korisnika kreativne industrije posredstvom medija razviti sopstvenu kreativnost i sklonost ka traganju za karijerom upravo na poljima kreative) na njihove izbore u budućnosti.

Evropska komisija kreirala je program „Kreativna Evropa" u cilju jačanja evropskih kulturnih i kreativnih sektora, na putu prilagođavanja digitalnom dobu i globalizaciji. Ovaj program izgrađen je na uspehu programa Kultura, MEDIA i MEDIA Mundus [12], a obezbeđuje podršku mnogobrojnim projektima koji imaju za cilj saradnju između kulturnih i kreativnih organizacija unutar EU i šire, putem realizacije projekata prekogranične saradnje.

U cilju uspešne saradnje medijskih kuća u državama EU, 1989. godine usvojena je direktiva o „televiziji bez granica“, kojom se uređuje minimalan skup pravila koja važe u svim državama EU. Jedan od ciljeva programa „Kreativna Evropa“ je da se na nivou cele EU formira jedinstveno tržište audiovizuelnih medija uz uspostavljanje bezbednijeg internet programa kako bi se širom EU zaštitila deca pri korišćenju interneta. „Kreativna Evropa“ obuhvata 33 zemlje učesnika od Norveške do Tunisa, kako članice EU, tako i države pridružene i predpristupne članice. Međudržavna saradnja pomaže očuvanju kulturnog nasleđa i raznolikosti uz digitalizaciju i globalizaciju [12], pogotovo imajući u vidu bogatstvo koje Evropka unija ima - 24 zvanična jezika, 3 pisma i oko 60 zvanično priznatih manjinskih jezika.

Prema istraživanjima Evropske komisije kulturni i kreativni sektori u zemljama članica čine 5,3\% BDP-a EU i zapošljavaju više od 12 miliona ljudi tj. 7,5\% radne snage EU [12], doprinoseći ekonomskom rastu, inovacijama, razvoju veština, utičući na unapređenje industrije turizma i informaciono komunikacionih tehnologija. 


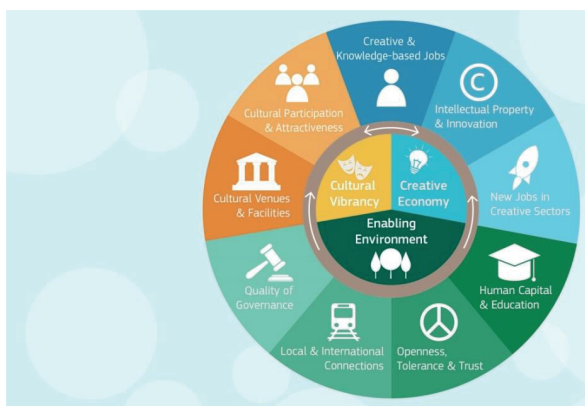

Slika 1. Konceptualni okvir i indikatori

kulturnih i kreativnih gradova

Izvor: www.ec.europa.eu [13]

Program „Kreativna Evropa“ obuhvata i razvoj i finansiranje projekta „Evropska prestonica kulture“. Ovaj program se temelji na ideji da se gradovi kroz kulturu, umetnost i kreativnost razvijaju i unapređuju kvalitet života i smisao življenja stanovnika u njemu, sa aspekta ekonomskog, kulturnog i socijalnog razvoja. Od formiranja i početka realizacije ovog programa 1985. godine preko 40 gradova na prostoru Evrope bilo je nosilac titule „Evropska prestonica kulture“.

Veoma značajno za Srbiju je realizovanje programa „Kreativna Evropa“ kroz projekat „Evropska prestonica kulture - Novi Sad 2021“ [14]. Dosadašnji pristup promotivnih kampanja u tradicionalnim medijima inoviran je implementacijom digitalnih/mobilnih aplikacija, sa idejom da se turisti/posetioci Novog Sada, a i stanovništvo upoznaju na interaktivan način sa bogatom kulturnom i istorijskom baštinom Novog Sada i okoline.

Prema Planu rada Fondacije „Novi Sad 2021“ [15] marketinške aktivnosti u vezi sa projektom „Evropska prestonica kulture Novi Sad 2021“ realizovaće se u formatima novih i tradicionalnih komunikacionih kanala: štampanim i elektronskim medijima, web prezentacije, mediji na otvorenom, audio i video produkcija, društvenim mrežama i sl. Implementacija mobilnih aplikacija, virtuelnih tura u sinergiji sa angažovanjem na društvenim mrežama na najsavremeniji način može doprineti promovisanju i razvoju kulturnih i kreativnih industrija na našem prostoru. [16]

\section{ZAKLJUČAK}

Analiza aspekata procesa medijske konvergencije i uticaja koji ovaj proces ima u radu kulturnih i kreativnih industrija ukazala je na dominantnu ulogu novih tehnologija i medija u domenu kreativnog poslovanja.
Niz primera ukazuje na činjenicu da se kreativnost može potpuno ispoljiti zahvaljujući upotrebi različitih tehnoloških ostvarenja, a da se njen puni domet može ostvariti tek kada se u date akcije uvedu različiti mediji. Danas je često moguće čuti da ako nešto nije na internetu, onda verovatno ne postoji. Takva tvrdnja može da nam posluži da objasnimo gore pomenutu tezu da bez medija kreativni izrazi ne bi bili vidljivi. S ozbirom na to da su (različiti) mediji vodeći kanali informisanja u 21. veku, svaki kreativni impuls moguće je poslati do krajnje adrese ukoliko se odabere adekvatan medij (vrsta medija, žanrovska pripadnost medijskog sadržaja i slično). Posmatrano iz drugog ugla, važno je pomenuti da ni medijska konvergencija kao proces ne bi bila izvodljiva kada ne bi bile razvijene kulturne i kreativne industrije, jer, bez obzira na informaciono-tehnološki razvoj, konvergencija medija ne bi ispunila svrhu svog postojanja bez postojanja kvalitetnog (dakle, kreativnog) sadržaja. Ovde možemo izneti zaključak da će u budućnosti medijska konvergencija, kao - kako kaže Dženkins - proces koji traje i koji se neće završiti, biti u velikoj meri oslonjena na kreativne impulse u različitim sektorima medija, a da će kulturne i kreativne industrije imati otvorena brojna medijska polja za kreaciju i promociju najrazličitijih vrsta poslovanja i stvaralaštva.

\section{LITERATURA}

[1] H. Jenkins, The cultural logic of media convergence, in International Journal of Cultural studies, 2004; 7; 33, p. 34.

[2] S. Crnobrnja, Estetika televizije i novih medija, Beograd: Klio, 2010, str. 256.

[3] S. Jovičić i H. Mikić, Kreativne industrije, Beograd: British Council, 2006, str. 18.

[4] N.Radović i D. Čigoja Piper, Tourism as a puzzle in the process of improvement of creative economy, SITCON 2016, Conference Proceedings, p. 34, 2016.

[5] D. Veličković i J. Veličković, Kreativne industrije i razumevanje faktora rasta, SINTEZA 2014, Conference Proceedings, p. 284, 2014.

[6] V. Kisić, Kulturne i kreativne industrije u Evropi, Kultura, br. 130, Zavod za proučavanje kulturnog razvitka, Beograd: 2011, str. 199-226., 211

[7] M. R. Solomon, O comportamento do Consumidor: Comprando, possuindo e sendo, 7 ed. Porto Alegre: Bookman, 2008.

[8] K. Salmon, Storytelling, Beograd: Klio, 2014.

[9] S. Milivojević, Uvod: novinarstvo za informaciono društvo, u CM - Časopis za upravljanje komuniciranjem, br. 24, sedma godina, Beograd: Fakultet političkih nauka; Novi Sad: Protokol, 2012, str. 30. 
[10] V. Kljajić, Novinarstvo u službi PR-a i marketinga u Godišnjak, Fakulteta političkih nauka, br. 2, Beograd: Fakultet političkih nauka, 2008. str. 277-287.

[11] L. Manovich, The Language of New Media, Cambridge, MA: MIT, 2001.

[12] Report from the Commission to the European Parliament and the Council - Mid-term evaliationof the Creative Europe programme 2014 - 2020, European Commission, Brussels, 2018.
[13] www.ec.europa.eu, pristupljeno 26.03.2019.

[14] T.Radojević, N.Radović i J.Petrović, EU funding programs for cultural tourism projects, SITCON 2018, Conference Proceedings, p. 339.

[15] www.novisad2021.rs, pristupljeno 26.03.2019.

[16] J.Gajić, I.Brdar, J.Stanković i R.Živković, Značaj upotrebe digitalne komunikacije u promociji kulturnog nasleđa - primer grada Novog Sada, SITCON 2018, Conference Proceedings, p. 210, 2018. 